\title{
VARIABILIDADE GENÉTICA EM BIOTIPOS DE LEITEIRO DE LONDRINA/PR ${ }^{1}$
}

\author{
MARIA JOSÉ V. DE VASCONCELOS ${ }^{2}$, RICARDO V. ABDELNOOR ${ }^{3}$, DÉCIO KARAN ${ }^{2}$, ÁLVARO M. R. ALMEIDA $^{3}$, \\ MAURÍLIO F. DE OLIVEIRA ${ }^{4}$, EVERALDO G. BARROS 5 e MAURÍLIO A. MOREIRA 5
}

\section{RESUMO}

Euphorbia heterophylla, também conhecida como amendoim-bravo ou leiteira, é considerada planta invasora importante em mais de 56 países, inclusive no Brasil, tendo acarretado perdas de até $33 \%$ na cultura da soja. Fenotipicamente, é uma espécie de características variáveis, especialmente em relação ao formato do limbo foliar. Esta variabilidade fenotípica tem sido utilizada para diferenciar e classificar as plantas, sugerindo a vários autores que a leiteira seria, de fato, constituída por diferentes espécies. Para estudar a variabilidade genética a nível de DNA entre plantas de Euphorbia heterophylla, que apresentam folhas morfologicamente diferentes, foram analisadas dez plantas diferentes coletadas em campos de soja, em Londrina/PR. As plantas foram transplantadas para casa-de- vegetação e o DNA das folhas foi extraído para análise pela técnica de RAPD. Vinte seis diferentes "primers", de dez nucleotídeos de sequência aleatória, geraram total de 102 bandas de DNA, sendo 38 delas polimórficas. A distância genética entre os indivíduos foi calculada em função da presença e da ausência das bandas, variando de 1 a $39 \%$ entre plantas. A análise de agrupamento dividiu as plantas em dois grupos, considerando limite de distância relativa de $22 \%$. Os grupos gerados separaram nitidamente as plantas quanto ao formato do limbo foliar (estreito ou arredondado) e quanto á ramificação (densa ou normal).

Palavras chave: Marcadores moleculares, diversidade genética, Euphorbia heterophylla.

\section{ABSTRACT}

\section{Genetic variability among Euphorbia heterophylla}

Euphorbia heterophylla is an important weed affecting the performance of annual and perennial crops. It is native from tropical and subtropical regions in the American continent, and has been detected at high densities in 20 different countries worldwide, and at low densities in other 40 countries. In Brazil, it has been inclued among the ten most important weeds affecting different crops, causing yield losses up to $33 \%$ in soybean fields. Phenotypically, this species is extremely variable, especially in relation to leaf shape and size, which can vary among and within populations. This variability suggested to several authors that E. heterophylla was, in fact, formed by different species. To systematize the study of E. heterophylla and to determine if the phenotypic variability correspond to modifications at the DNA level, we analyzed 10 different plants collected in the soybean field in Londrina (Parana, Brazil). The plants were transplanted to the

\footnotetext{
${ }^{1}$ Recebido para publicação em 23/06/99 e na forma revisada em 16/09/99.

${ }^{2}$ Embrapa Milho e Sorgo. Rod. MG 424 - Km 65, C.P. 151, CEP: 35.701-970, Sete Lagoas/MG. E-mail: mjose@cnpms.embrapa.br.

${ }^{3}$ Embrapa Soja, Londrina/PR.

${ }^{4}$ Recém-Doutor, CNPq/Embrapa Milho e Sorgo.

${ }^{5}$ BIOAGRO, UFV. Viçosa/MG.
} 
greenhouse and leaf DNA was extracted for RAPD technique analysis. Twenty-six RAPD "primers" different amplified 102 DNA bands, 38 of them being polymorphic. Genetic distances among the individuals were calculated based on the presence (1) or absence (0) of those bands. Cluster analyses divided the plants into two

\section{INTRODUÇÃO}

Euphorbia heterophylla, também conhecida no Brasil como amendoim-bravo, leiteiro ou flor-de-pelota é uma planta importante por afetar a produtividade de cerca de 31 culturas anuais e perenes em 56 países. Essa planta é nativa de regiões tropicais e subtropicais do continente americano ocorrendo também em muitos países da África e Ásia. O nome dado à espécie expressa a grande variação encontrada nas folhas das plantas (Holm et al., 1997).

A importância agrícola dessa planta devese à sua freqüente presença como invasora em culturas importantes economicamente, como soja, milho e cana-de-açúcar, tanto em plantio direto quanto convencional. No Brasil, a leiteira infesta cerca de $25 \%$ dos campos de soja, sendo que essa cultura tolera altas populações dessa invasora (Holm et al., 1997). Trabalhos citados por Holm et al. (1997), descrevem que a densidade de 75 plantas $/ \mathrm{m}^{2}$ de leiteira reduziu o rendimento em $12 \%$, e densidades de 300 e 600 plantas $/ \mathrm{m}^{2}$ acarretaram perdas de rendimento de 23 e $33 \%$, respectivamente. No Sul dos Estados Unidos, essa invasora também tem acarretado perdas, onde 8 plantas/m de fileira de soja competindo por 8 e 12 semanas, e durante todo o ciclo da cultura, reduziram a produção em 19, 21 e 33\%, respectivamente. Esse autor descreve, ainda, que densidade de 50 plantas $/ \mathrm{m}$ frequientemente resulta em perdas totais das lavouras de soja. Além das perdas por competição, a Euphorbia heterophylla é considerada planta tóxica e hospedeira de pragas e doenças, como o vírus do mosaico e da bactéria causadora do murchamento da mandioca. Em alguns países, as folhas e caule são utilizados distinct groups considering an upper limit of $22 \%$ relative genetic distance. The genetic distances among the plants were between 1 and 39\%, in agreement with the variability obseved at the morphological level.

Key words: Molecular markers, genetic divergence, Brazil, wild poisentia.

como purgantes e o látex para tratamentos localizados de erisipela (Holm et al., 1997).

A leiteira apresenta ciclo anual, porte médio de 40 a $60 \mathrm{~cm}$, é altamente competitiva, com rápidos crescimento e multiplicação (Kissmann \& Groth, 1992). O caule é simples ou ramificado, as folhas são alternas, opostas ou verticiladas ocorrendo tanto no caule como nos ramos. O formato do limbo foliar é bastante variável sendo classificado em ovalado, panduriforme (formato de violino) e lanceolado (Cronquist, 1981; Kissmann \& Groth, 1992). Apresenta ciclo de germinação e frutificação curtos, podendo ocorrer de duas a quatro gerações no período de um ano (Kissmann \& Groth, 1992), podendo reproduzir tanto por autofecundação quanto por fecundação cruzada (Cronquist, 1981; Barroso, 1984).

Fenotipicamente, esta espécie é extremamente variável, especialmente em relação à forma e tamanho da folha, podendo apresentar variações de uma população para outra, dentro de uma mesma população, entre descendentes de uma mesma planta e até mesmo em uma única planta (Kissmann \& Groth, 1992; Holm et al., 1997). Existem plantas com apenas um desses padrões, e outras delas que apresentam padrões mistos. A variabilidade no formato das folhas sugere que a espécie ainda esteja em evolução (Kissmann \& Groth, 1992) e tem sido utilizada para sugerir que a Euphorbia seria, de fato, formada por diferentes espécies. Entretanto, a classificação dessa planta ainda não está bem definida, pois diferentes autores a classificam de diferentes formas. Segundo Kissmann \& Groth (1992), alguns autores a descrevem como três espécies: $E$. geniculata, E. prunifolia e E. zonosperma, enquanto alguns botânicos tentaram 
estabelecer variedades dentro de uma espécie. Outros consideram apenas E. heterophylla, considerando como sinônimos E. geniculata, E. prunifolia, E. zonosperma e Poinsettia heterophylla. Holm et al. (1997) e Kissmann e Groth (1992) optaram por apresentar duas espécies infestantes: Euphorbia heterophylla e Euphorbia prunifolia, diferindo basicamente quanto ao formato da folha, sendo bastante variável na primeira e regularmente elíptico na segunda espécie. Estudos realizados por Vargas citados por Krissmann e Groth (1992), utilizando várias gerações de autofecundação de plantas isoladas com mesmo padrão de folhas, têm conseguido fixar essa característica, indicando que essa infestante está relacionada à duas espécies.

Vários autores têm utilizado os marcadores do tipo RAPD, descritos por Williams et. al. (1990), e AP-PCR, descritos por Welch \& McClelland (1990), para caracterizar plantas e microrganismos. O uso desta metodologia tem sido bastante útil na avaliação da diversidade genética entre indivíduos de uma mesma espécie ou de espécies diferentes. Abdelnoor (1994) caracterizou 38 genótipos de soja podendo inferir sobre a variabilidade genética do germoplasma de soja utilizado no Brasil. Vasconcelos et al. (1996), utilizando marcador tipo RAPD, verificaram que a variabilidade genética de 28 cultivares de feijão pode ser separada em sete grupos, enquanto que utilizando marcadores isoenzimáticos, estes mesmos cultivares, só puderam ser separados em dois grandes grupos, os quais correspondiam aos seus centros de origem e domesticação. Abad et al. (1998), utilizando RAPD, verificaram alto nível de variabilidade genética em clones de Cyperus esculentus cultivados e amostrados como invasora na Espanha. Rowe et al. (1997) atribuíram o alto grau de variabilidade genética encontrada em Euphorbia escula, nos Estados Unidos, à possíveis introduções múltiplas da espécie ou ao elevado grau de variabilidade dentro das populações nativas.

O objetivo desse trabalho foi avaliar a variabilidade genética no nível do DNA, extraído de folhas morfologicamente diferentes de plantas de Euphorbia heterophylla provenientes de Londrina/PR.

\section{MATERIAL E MÉTODOS}

Foram coletadas dez plantas, fenotipicamente diferentes, de Euphorbia heterophylla em um campo de soja, em Londrina/PR. Essas plantas foram transplantadas para casa-de-vegetação. Foi coletada uma amostra de folhas de cada planta, com exceção de uma, da qual foram coletadas duas amostras, uma vez que esta planta apresentou um ramo com tipo de folha diferente do restante da planta (amostras 8 e 9), totalizando 11 amostras (Tabela 1).

A extração de DNA das folhas foi realizada no Laboratório de Genética Molecular do Bioagro, UFV. As folhas foram maceradas na presença de nitrogênio líquido, o DNA extraído com CTAB 1\%, precipitado em álcool e ressuspenso em Tris-EDTA (TE) pH 8, de acordo com Sambrook et al. (1989).

As reações de amplificação foram feitas em um volume total de $25 \mu \mathrm{l}$, contendo $10 \mathrm{mM}$ de Tris- $\mathrm{HCl}(\mathrm{pH} 8,3), 50 \mathrm{mM}$ de $\mathrm{KCl}$, $2 \mathrm{mM}$ de $\mathrm{MgCl}_{2}, 100 \mu \mathrm{M}$ de dATP, dTTP, dGTP e $\mathrm{dCTP}, 0,4 \mu \mathrm{M}$ de "primer", 1 unidade da enzima Taq-DNA-polimerase e $30 \mathrm{ng}$ de DNA. As amplificações foram feitas no termociclador Perkin-Elmer 9600, programado para 40 ciclos de 15 segundos a $94^{\circ} \mathrm{C}, 30$ segundos a $35^{\circ} \mathrm{C}$ e 1 minuto a $72^{\circ} \mathrm{C}$ e uma etapa final de 7 minutos a 72 ${ }^{\circ} \mathrm{C}$. Foram utilizados 26 "primers" randômicos cujas sequências dos oligonucleotídeos decâmeros estão listadas na Tabela 2.

Os produtos de amplificação foram analisados por eletroforese em géis de agarose 1,2\% em tampão TBE e visualizados sob luz ultravioleta através de coloração em solução de brometo de etídio.

Os dados obtidos foram coletados na forma de presença (1) ou ausência (0) de bandas. A distância genética entre as plantas foi calculada utilizando o programa "Statistica" for Windows, v. 5.2 . 
Com base nas distâncias genéticas obtidas foi elaborado um dendrograma utilizando o método UPGMA e realizada a análise multivariada com as 11 amostras.

TABELA 1. Identificação e descrição morfológica das 11 amostras de folhas de Euphorbia heterophylla.

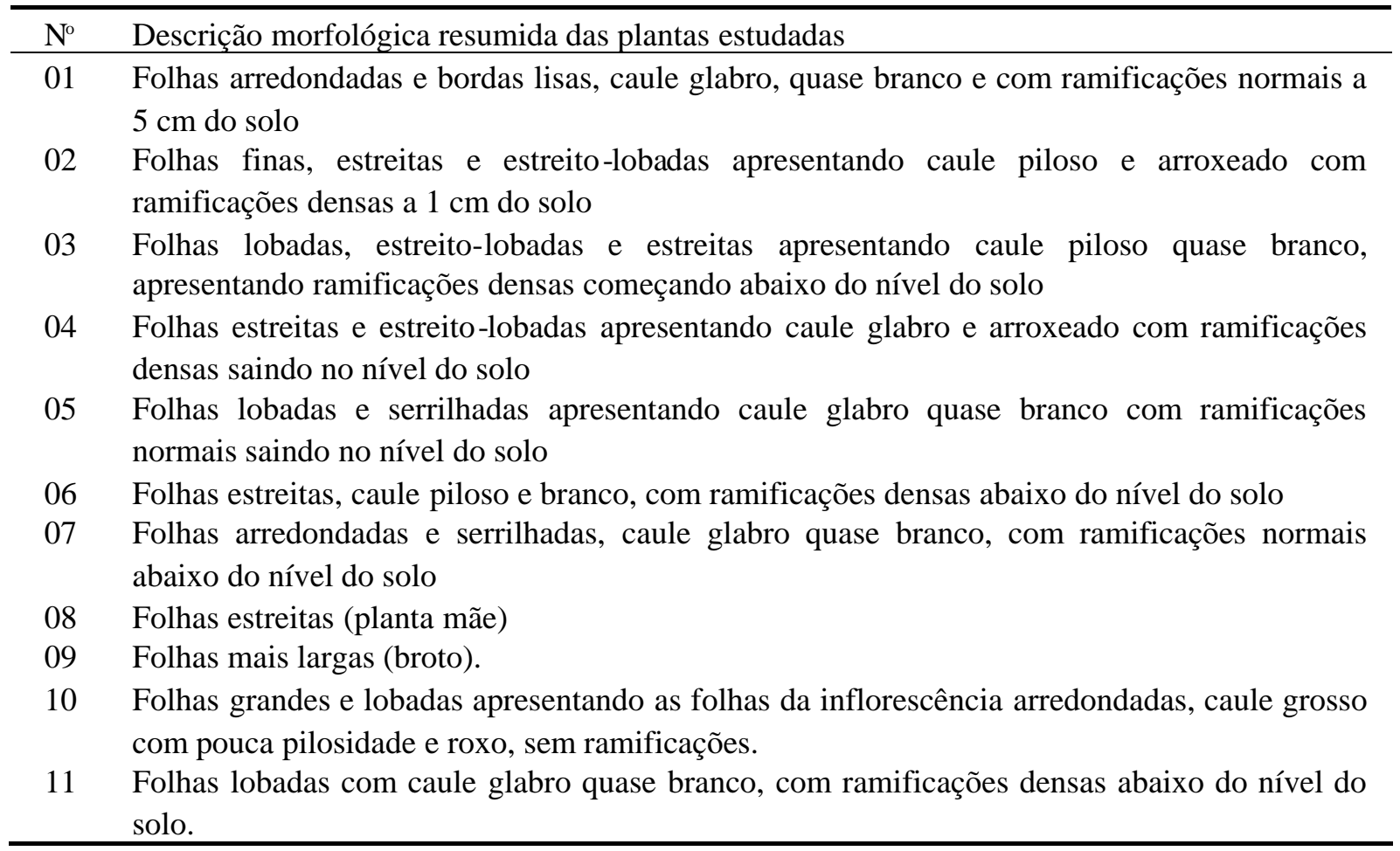

TABELA 2. Identificação e sequência dos 26 "primers" randômicos utilizados como marcadores RAPD.

\begin{tabular}{llll}
\hline \multicolumn{1}{c}{ "PRIMER" } & SEQUÊNCIA & "PRIMER" & SEQUÊNCIA \\
\hline OPH-11 & CTTCCGCAGT & OPAD-17 & TTTCCCACGG \\
OPAA-02 & TGCCGAGCTG & OPAD-18 & CTGGGGACTT \\
OPAC-10 & TGTCTGGGTG & OPAF-18 & TTCCCGGGTT \\
OPAC-12 & TGTCATCCCC & OPAF-19 & CCTCTAGACC \\
OPAC-19 & GTTGCCAGCC & OPAF-20 & GGTCTAGAGG \\
OPAC-20 & ACTTCGCCAC & OPAG-01 & CTACGGAGGA \\
OPAD-01 & ACCGCGAAGG & OPAG-19 & GTCAGGGCAA \\
OPAD-02 & GGACCCAACC & OPAG-20 & TCTCCCTCAG \\
OPAD-04 & TCTGGTGAGG & OPAH-19 & CTGACCAGCC \\
OPAD-08 & GTGTGCCCCA & OPAH-20 & GGGAGACATC \\
OPAD-09 & CTCTGGAGAC & OPAI-14 & TGACGGCGGT \\
OPAD-10 & GGTCTACACC & OPAI-19 & AATGCGGGAG \\
OPAD-11 & AGCGCCATTG & OPAI-20 & AAAGTGCGGG \\
\hline
\end{tabular}




\section{RESULTADOS E DISCUSSÃO}

Com a utilização dos 26 "primers" foi obtido total de 102 produtos de amplificação (Figura 1). Nove desses "primers" não apresentaram qualquer polimorfismo entre as plantas analisadas, amplificando um total de 23 bandas monomórficas. Dezessete dos "primers" geraram 38 bandas polimórficas e 41 monomórficas.

Com base nos dados moleculares foram calculadas as distâncias genéticas entre as plantas avaliadas (Tabela 3), que variaram de 1 a $39 \%$. A menor distância foi obtida entre as amostras 8 e 9 , pertencentes à mesma planta, apenas oriundos de ramos morfologicamente diferentes (Tabela 1), como seria esperado. Essa planta, conforme descrição realizada por Kissmann \& Groth (1992) demonstra que as diferenças morfológicas quanto ao formato da folha, podem ser identificadas a nível de DNA, mesmo sendo diferenças muito pequenas. $\mathrm{O}$ maior valor de distância genética (39\%) foi obtido entre as plantas 03 e 10 , que apresentam diferenças morfológicas quanto a pilosidade, cor do caule, tipo de ramificação e formato do limbo foliar (Tabela 1). O nível de diversidade genética obtido está de acordo com Abad et al. (1989) que afirma, citando Barret (1982), que populações de espécies daninhas, frequentemente, exibem limitada variação genética quando comparadas com outros tipos de plantas.

Quanto ao formato do limbo e à ramificação das plantas estudadas, observa-se na Tabela 3 que, de modo geral, a distância genética foi maior entre as plantas com folhas estreitas e ramificações densas e aquelas que possuem folhas arredondadas ou lobadas e ramificações normais ou ausentes, em especial as combinações da planta 01 com as demais. Nessas combinações, os maiores valores de distância genética (superiores a $31 \%$ ) foram obtidos com as plantas $02,03,04,06$ e 11. Tais plantas, ao contrário da planta 01, possuem folhas estreitas e ramificação densa.

Pela análise de agrupamento (Figura 2), os genótipos puderam ser divididos em dois grupos, considerando o nível de $22 \%$ de distância genética relativa. Estes grupos estão abaixo relacionados, juntamente com os indivíduos que os compõem:

Grupo A: 01; 05; 07; 08; 09 e 10

Grupo B: 02; 03; 04; 06 e 11

Verifica-se que as plantas pertencentes ao grupo B apresentam similaridade quanto ao formato do limbo foliar (estreito, estreito-lobado e lobado) e a ramificação do caule (densa) (Tabela 1). Além disso, podemos observar o melhor agrupamento das plantas pertencentes ao grupo B, cuja distância genética variou de 3 a $16 \%$ dentro do grupo. No entanto, o grupo A apresentou uma maior variação na distância genética dentro do grupo, sendo esta de 1 a $24 \%$ (Tabela 3). Esses resultados indicam que o formato do limbo foliar é uma característica muito importante na identificação e classificação das plantas de Euphorbia heterophylla. Tais resultados reforçam as descrições realizadas por Kissmann \& Groth (1992).

A análise multivariada realizada com os resultados de distância genética e de agrupamento confirmaram a distribuição espacial das 11 amostras de folhas estudadas em 2 grupos distintos, possibilitando a melhor visualização da distribuição dos grupos (Figura 3).

Os resultados indicam que, além dos vários fatores que determinam a estrutura genética, a variabilidade morfológica encontrada na leiteira pode ser também atribuída à sua plasticidade fenotípica (Abad et al., 1998). Embora trabalhos adicionais possam ser realizados com número maior de "primers" e de indivíduos para confirmar os resultados obtidos nesse trabalho inicial, os resultados do presente trabalho indicam que a técnica de RAPD pode ser utilizada para caracterizar e agrupar biotipos de leiteira, particularmente quanto a morfologia da folha. Nesse estudo 17 "primers" puderam descriminar as plantas avaliadas. Esse método oferece um caminho rápido e relativamente barato para detectar pequenas diferenças genéticas entre indivíduos contrastantes para determinadas características de interesse. 
TABELA 3. Distância genética (\%) entre as 11 amostras de folhas de Euphorbia heterophylla.

\begin{tabular}{|c|c|c|c|c|c|c|c|c|c|c|c|}
\hline & 1 & 2 & 3 & 4 & 5 & 6 & 7 & 8 & 9 & 10 & 11 \\
\hline 1 & 0 & & & & & & & & & & \\
\hline 2 & 34 & 0 & & & & & & & & & \\
\hline 3 & 31 & 8 & 0 & & & & & & & & \\
\hline 4 & 36 & 3 & 10 & 0 & & & & & & & \\
\hline 5 & 24 & 20 & 28 & 17 & 0 & & & & & & \\
\hline 6 & 32 & 4 & 11 & 6 & 19 & 0 & & & & & \\
\hline 7 & 21 & 22 & 25 & 25 & 10 & 19 & 0 & & & & \\
\hline 8 & 24 & 20 & 28 & 22 & 22 & 16 & 17 & 0 & & & \\
\hline 9 & 22 & 21 & 26 & 24 & 24 & 17 & 19 & 1 & 0 & & \\
\hline 10 & 17 & 31 & 39 & 31 & 14 & 28 & 14 & 11 & 13 & 0 & \\
\hline 11 & 36 & 13 & 15 & 13 & 20 & 16 & 20 & 28 & 29 & 29 & 0 \\
\hline
\end{tabular}

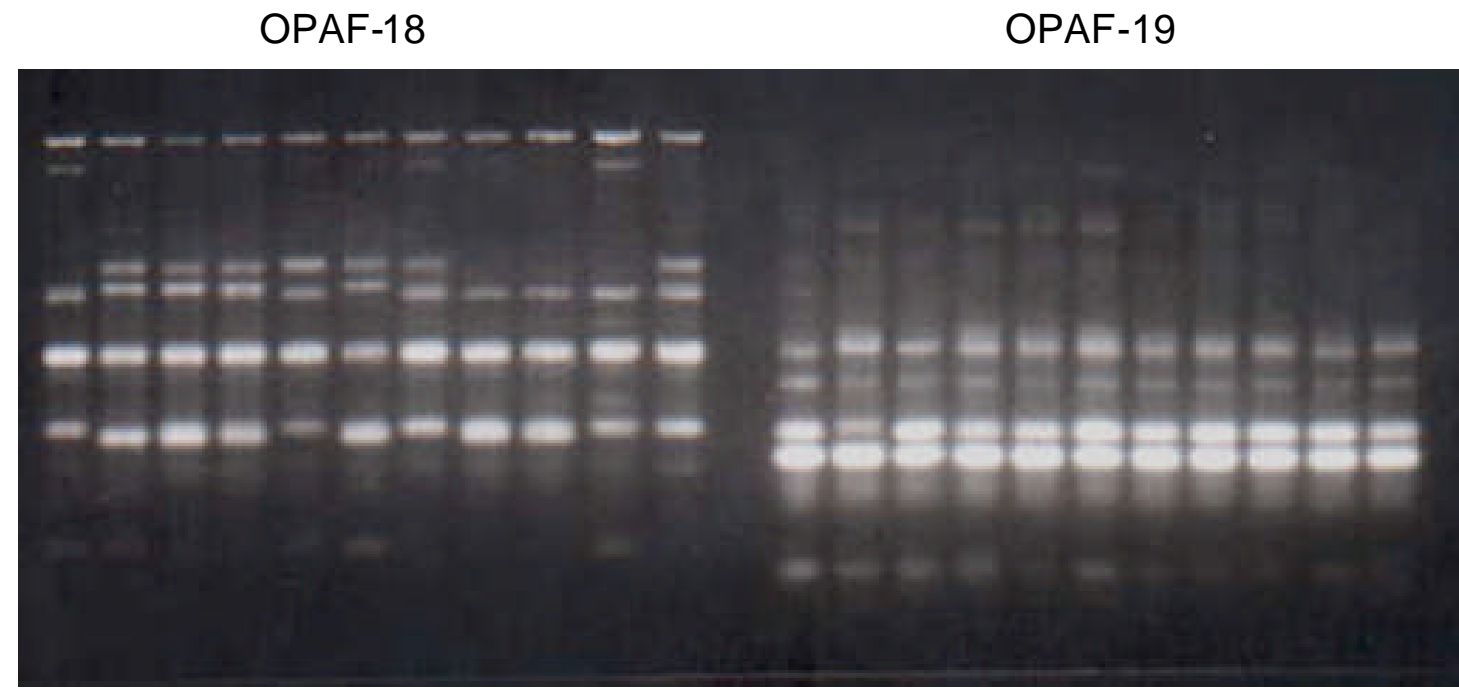

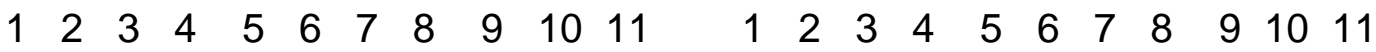

FIGURA 1. Produto de amplificação do DNA genômico das 11 amostras de folhas de Euphorbia heterophylla (conforme descrição na Tabela 1) utilizando "primers" decâmeros randômicos OPAF-18 (polimórfico) e OPAF-19 (monomórfico). As linhas apresentam: 1 - 11 Biotipos de Euphorbia heterophylla. 
Variabilidade genética em biotipos de leiteiro de Londrina/PR

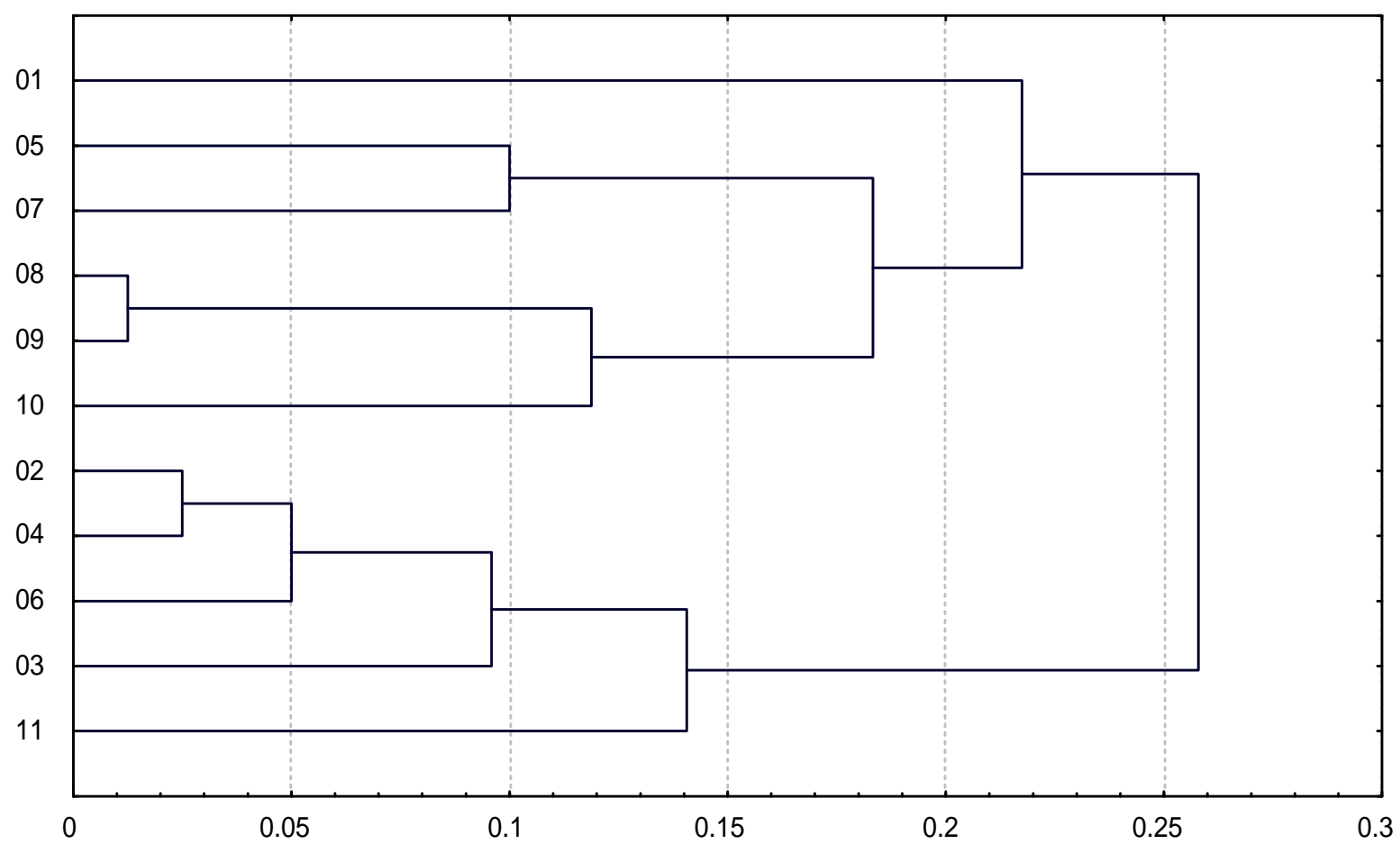

FIGURA 2. Dendrograma das 11 amostras de folhas de Euphorbia heterophylla basedo em dados de RAPD.

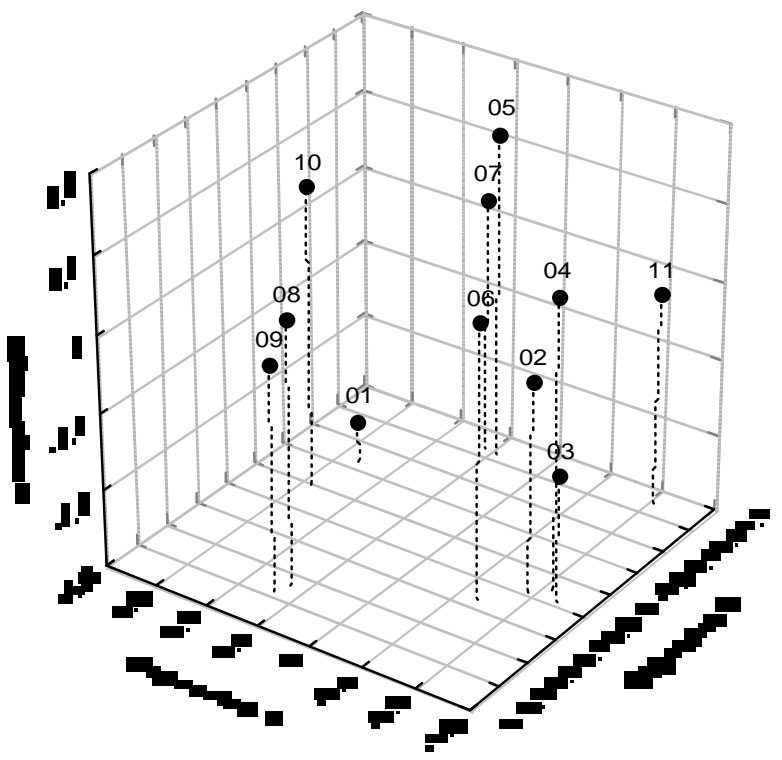

FIGURA 3. Projeção das 11 amostras de folhas de Euphorbia heterophylla no espaço tridimensional utilizando análise de componentes principais. 


\section{LITERATURA CITADA}

ABAD, P.; PASCUAL, B.; MAROTO, J. V.; LÓPEZ-GALARZA, S.; VICENTE, M. J.; ALAGARDA, J. RAPD analysis of cultivated and wild yellow nutsedge (Cyperus esculentus L.). Weed Sci., v. 46, n. 2, p. 318-321. 1998.

ABDELNOOR, R. V. Uso de marcadores moleculares na avaliação da diversidade genética em cultivares de soja (Glycine $\max ($ L) Merrill). Viçosa, UFV. 53p. 1994 (Tese-M.S).

BARROSO, G. M. Sistemática de angiospermas do Brasil. Universidade Federal de Viçosa. Viçosa, Vol II. Viçosa, Imprensa Universitária, 1984. p. 199-206.

CRONQUIST, A. An integrated system of classification of flowering plants. New York, 736-740 p. 1981.

HOLM, L.; DOLL, J.; HOLM, E.; PANCHO, J.; HERBERGER, J. World Weeds: Natural Histories and Distribution. John Wiley \& Sons, 1997.

KISSMANN, K. G.; GROTH, D. Plantas infestantes e nocivas. TOMO II. São Paulo: Basf Brasileira S. A. 798 p. 1992.
ROWE, M. L.; LEE, D. J.; NISSEN, S. J.; BOWDITCH, B. M.; MASTERS, R. A. Genetic variation in North American leafy spurge (Euphorbia escula) determined by DNA markers. Weed Sci., v. $45, \quad$ n. $2, \quad$ p. $446-454$. 1997.

SAMBROOK, J.; FRITSCH, E.F.; MANIATIS, T. Molecular cloning: a laboratory manual. 2 ed. New York, Cold Spring Harbor Laboratory Press, 1989. v.3.

VASCONCELOS, M. J. V.; BARROS, E. G.; MOREIRA, M. A.; VIEIRA, C. Genetic diversity of common bean Phaseolus vulgaris $\mathrm{L}$. determined by DNA-based molecular markers. Braz. J. genet., v. 19, n. 3, p. 447-451. 1996.

WELSH, J.; McCLELLAND, M. Fingerprinting genomes using PCR with arbitrary primers. Nucleic Acids Res., v. 18, n. 24, p. 72137218. 1990.

WILLIAMS, J. G. K.; KUBELIK, A. R.; LIVAK, K. J.; RAFALSKI, J. A.; TINGEY, S. V. DNA polymorphism amplified by arbitrary primers are useful as genetic markers. Nucleic Acids Res., v. 18, n. 22, p. 6531-6535. 1990. 